\title{
Popularity of Herbal Medicine
}

HADI ALNAJJAR, Ph.D.; HUSSAM ALKOOT, M.Sc. and MARIAM ALHUSSAINI, Ph.D.

The Department of Pharmacy, College of Health Sciences, PAAET Kuwait

\begin{abstract}
Background: Herbal remedies play a major roll in the folcloric nature of Kuwaity community. Old remedies and priscriptions are passed down through genirations. You may find dry opium capsules in some household chest of medicine that is ued for insomnia despite its illigality. There is no clear bounderies between legal herbal products both as crud or as packaged pharmaceutical products verses the ordinary so called chemical products.
\end{abstract}

The WHO herbal Act of 1986, in which I was the representative of Kuwait was an attempt to set guidelines defining herbal products and the laws of import and export of such drugs.

Aim of Study: As an attempt to obtaine feedback from our community about the popularity of such systems of treatments, this study aims to identify the popularity of herbal remedies compared to chemical remedies for future legistlative acts.

Matrial and Methods: The study was carried out amongst students at the College of Health Sciences in the State of Kuwait. The effect of the variables of specialization and gender was measured. This study adopts the descriptive approach and data have been collected through a questionnaire applied to the sample of the study of male and female students at the College of Health Sciences.

Results: The study's results show that there are statistically significant differences (0.05) among the responses of the study sample's individuals regarding the following domains: Herbal (HB), Orthodox (OR), legislation, and general information due to the variable of gender in favor of females while there are no differences regarding the domain of supplemental and beauty products. Additionally, the results indicate that there are statistically significant differences regarding the following domains: Herbal (HB) and Orthodox (OR) due to the variable of specialization while there are no differences regarding the domain of supplemental and beauty products, legislation, and general information.

Concllusion: The results display that most of the sample's individuals prefer and recommend using herbal remedies, and that they like beauty cosmetics made of herbal drugs. Also, most of the sample's individuals believe in the importance of having centers that provide herbal treatment in Kuwait stating

Correspondence to: Dr. Hadi Alnajjar, The Department of Pharmacy, College of Health Sciences, PAAET Kuwait that a great number of patients in Kuwait have no knowledge about these centers. Furthermore, some of the study sample's individuals believe that it is important to use chemical remedies in the acute cases and that both herbal and chemical remedies complement each other.

Key Words: Herbal medicine - Ortodox - Popularity - Preference-Beauty products.

\section{Introduction}

THERE is a lot of published literature on this subject matter: Marakova, et al. studied the active constituents in herbal products [1,2]. Laualan, et al., studied traditional Chinese medicine including acupuncture and herbs in treating Alzheimer [3] .

Neelo, et al., in turn looked into herbal medicine and homeopathy in female fertility problems [4] Sahoo, et al., shaded some light on patenting herbal drugs in India due to their distinct advantages [5] Liu, et al., also wrote about the contributions of herbal medicine and their advantages over the last 5000 years [6]. Duke also mentioned the advantages of herbal products over chemical drugs [7].

Some applied the study on medical, Pharmacy and Nursing students [8-13]. Others compared between adults and children [14]. Others studied its popularity in general like studies carried out in the Emirates, Reyad, Japan [15-17].

\section{Subjects and Methods}

Methodology and procedures of the study: Methodology of the study:

The current study adopts the descriptive approach as it suits the nature of the study and it enables the researcher to describe the phenomenon under study, to analyze its data, and to reveal the relationship between its components and the opinions regarding it, the processes it has and effects it causes. 


\section{Community and sample of the study:}

The study's community includes the students at the College of Health Sciences in the Public.

Authority for Applied Education and Training in the State of Kuwait, and the study's sample consists of (182) students at the College of Health Sciences divided into (68) males and (114) females. It was carried out during the academic years 20172020.

\section{Tool of the study:}

The tools of the study include a questionnaire that consists of (36) statements distributed to five axes. The questionnaire aims to identify the popularity of herbal remedies compared to chemical remedies among the students at the College of Health Sciences in the State of Kuwait.

Each statement has five levels to the answer in accordance with Likert 5 point scale as follows:

Very satisfied (5 marks), satisfied (4 marks), neutral (3 marks), unsatisfied (2 marks), and very unsatisfied (1 mark).

\section{Validity of the questionnaire:}

The validity of the questionnaire has been verified through:

A- Face validity (validity of Juries): The questionnaire has been judged by a number of specialized juries at the College of Health Sciences and it was amended according to their suggestions where some statements have been linguistically paraphrased, and the final form of the questionnaire consists of (36) statements. The consensus of the juries ensures the validity of the content of the questionnaire.

$B$ - The internal consistency of the questionnaire: The internal consistency of the questionnaire has been verified through the calculation of the correlation coefficient of each statement and the axe it belongs to as obtained from the survey study that had been applied on a sample of (40) male and female students at the College of Health Sciences in Kuwait.

The results of the study display that all the correlation coefficients between each statement and the axe it belongs to is high and statistically significant at the significance level (0.01), and that the correlation coefficients among the statements of the axe Herbal (HB) ranged between (0.400$0.634)$, the correlation coefficients among the statements of the axe Orthodox (OR) ranged between (0.422-0.596), the correlation coefficients among the statements of the axe supplemental and beauty products ranged between (0.486-0.588), the correlation coefficients among the statements of the axe legislation ranged between (0.589-0.703), and the correlation coefficients among the statements of the axe general information ranged between (0.406-0.538). This confirms that the internal consistency of the questionnaire and thus the validity of the content. Also, the correlation coefficient of each axe and the total degree of the questionnaire has been calculated and this can be illustrated in the following table.

Table (1): The correlation coefficient of each axe and the total degree of the questionnaire.

\begin{tabular}{lc}
\hline Axe & Correlation coefficient \\
\hline Herbal (HB) & $0.772 * *$ \\
Orthodox (OR) & $0.784 * *$ \\
Supplemental and beauty products & $0.544 * *$ \\
Legislation & $0.603 * *$ \\
General information & $0.744 * *$ \\
\hline
\end{tabular}

**: Correlation is significant at the (0.01) level.

Based on the above table, it is obvious that all the correlation coefficients between each statement and the total degree of the questionnaire are statistically significant at the significance level (0.01), and the correlation coefficients range between (0.544-0.784). This confirms the internal consistency and thus the validity of the construction.

\section{Reliability of the questionnaire:}

Reliability's coefficient has been calculated through finding Cronbach's alpha coefficient for each theme in the questionnaire by using the SPSS after applying it on the sample of the survey. The results are shown in the following table.

Table (2): Reliability coefficients of the axes in the questionnaire.

\begin{tabular}{lcc}
\hline Axe & $\begin{array}{c}\text { Statements } \\
\text { No. }\end{array}$ & $\begin{array}{c}\text { Reliability } \\
\text { coefficient }\end{array}$ \\
\hline Herbal (HB) & 11 & 0.82 \\
Orthodox (OR) & 10 & 0.81 \\
Supplemental and beauty products & 5 & 0.87 \\
Legislation & 4 & 0.86 \\
General information & 6 & 0.84 \\
\hline Total & 36 & 0.87 \\
\hline
\end{tabular}

As indicated by the above table, the reliability's coefficient of the questionnaire as whole is high and has reached (0.87) and that reliability's coefficient of the axes is also high and range between (0.81-0.87). Thus the results can be trusted and regarded as reliable when applying them on the basic sample of the study. For the purposes of judging the extent of the popularity of herbal remedies as compared to chemical remedies among 
the students at the College of Health Sciences in accordance with the categories of Likreet fithe measurement used to answer the statements of the questionnaire, the responses of the study sample's individuals could be classified into three levels to make the process of interpreting the results easy. This can be done using the following equation:

Length of the category $=$ Range - Number of levels (high - moderate - low).

Range $=$ The highest values of answers categories (5) - the lowest values of answers categories $=5-1=4$.

Thus the length of the category $=4-3=1.33$ and then adding the answer (1.33) to the end of each category.

\section{Therefore:}

A- The minimum level $=1+1.33=2.33$

B- The moderate level $=2.34+1.33=3.67$

C- The Maximum level $=3.67$ and more

Hence, measures will have the following value:

- The means that ranges between (3.68-5) indicates that the popularity of herbal and chemical remedies among the students at the College of Health Sciences is high.

- The means that ranges between (2.34-3.67) points out that the popularity of herbal and chemical remedies among the students at the College of Health Sciences is moderate.

- The means that ranges between (1.00-2.33) shows that the popularity of herbal and chemical remedies among the students at the College of Health Sciences is low.

The statistical methods used in the current study: Data entry has been done using the computer through the SPSS conducting the following statistical treatments to provide answers for the questions of the study:

- Frequencies.

- Percentages.

- Means.

- Standard deviations.

- Independent Samples $t$-test.

- One Way ANOVA.

- LSD test.

\section{Results}

Results of the study:

This part displays the results of the study after conducting the statistical analysis of data. To answer the questions of the study, the responses of the study sample individuals have been collected and treated statistically using the SPSS to find the means and standard deviations for each statement in the questionnaire. The next section is concerned with displaying the results of the study.

\section{Results of the first question:}

What is the extent of popularity of herbal remedies compared with chemical remedies among the students at the College of Health Sciences in Kuwait?

To identify the extent of popularity of herbal remedies compared with chemical remedies among the students at the College of Health Sciences in Kuwait, the recurrences, percentages, means, and standard deviations of each statement in the questionnaire have been calculated and arranged according to the means as illustrated by the following tables.

Table (3): Percentages, means, and standard deviations of study sample individuals' responses concerning Herbal (HB).

\begin{tabular}{|c|c|c|c|c|c|c|c|c|c|}
\hline \multirow{2}{*}{ No } & \multirow{2}{*}{ Statements } & \multicolumn{5}{|c|}{ Percentages } & \multirow{2}{*}{ Mean } & \multirow{2}{*}{$\begin{array}{c}\text { Std. } \\
\text { deviation }\end{array}$} & \multirow{2}{*}{$\begin{array}{l}\text { Order } \\
\text { according } \\
\text { to mean }\end{array}$} \\
\hline & & $\begin{array}{c}\text { Strongly } \\
\text { disapprove }\end{array}$ & Disapprove & $\begin{array}{c}\text { No } \\
\text { comment }\end{array}$ & Approve & $\begin{array}{l}\text { Strongly } \\
\text { approve }\end{array}$ & & & \\
\hline 1 & - I prefer herbal treatments. & 0 & 4.95 & 15.38 & 48.35 & 31.32 & 4.06 & 0.82 & 1 \\
\hline 3 & - Herbalism has fewer side effects. & 3.85 & 7.69 & 12.09 & 48.35 & 28.02 & 3.89 & 1.02 & 2 \\
\hline 5 & - Whole drugs are used in herbal treatments. & 9.34 & 21.43 & 27.47 & 32.42 & 9.34 & 3.11 & 1.13 & 10 \\
\hline 7 & $\begin{array}{l}\text { Whole drugs contain balanced active } \\
\text { constituents that enhance each other and } \\
\text { minimize side effects. }\end{array}$ & 2.75 & 4.95 & 25.27 & 46.15 & 20.88 & 3.77 & 0.93 & 4 \\
\hline 8 & - Herbal drugs need a long time to show effects. & 2.20 & 13.19 & 19.23 & 45.05 & 20.33 & 3.68 & 1.01 & 5 \\
\hline 10 & $\begin{array}{l}\text { - Herbs contain minute counties of active } \\
\text { constituents. }\end{array}$ & 3.85 & 7.69 & 29.67 & 47.80 & 10.99 & 3.54 & 0.93 & 7 \\
\hline 11 & - $\mathrm{Hb}$ is better for chronic cases. & 9.89 & 19.23 & 17.58 & 35.16 & 18.13 & 3.32 & 1.25 & 6 \\
\hline 14 & - I feel more confident in using $\mathrm{Hb}$. & 8.24 & 12.64 & 13.19 & 44.51 & 21.43 & 3.58 & 1.19 & 9 \\
\hline 17 & - I feel reluctant in taking $\mathrm{Hb}$. & 12.92 & 40.45 & 14.61 & 24.72 & 7.30 & 2.73 & 1.18 & 11 \\
\hline 28 & - I recommend $\mathrm{Hb}$ & 2.75 & 11.54 & 15.38 & 42.86 & 24.47 & 3.81 & 1.05 & 3 \\
\hline 34 & $\begin{array}{l}\text { - Hb centers treat the cause of illness once and } \\
\text { for all. }\end{array}$ & 5.49 & 15.93 & 27.47 & 36.26 & 14.84 & 3.39 & 1.09 & 8 \\
\hline
\end{tabular}


Based on the above table, it is notable that the Herbal (HB) axe has (11) statements and that (5) statements recorded a high degree as their means ranged between (3.68-4.06). There is also a remarkable variance in the study sample individuals' responses in regard to these statements that got the following arrangement: Statement no. (1) "I prefer herbal treatments" got the first rank (M.=4.06). Statement no. (3) "Herbalism has fewer side effects" got the second rank (M.=3.89). Statement no. (28) "I recommend $\mathrm{Hb}$ " got the third $\operatorname{rank}(\mathrm{M} .=3.81)$.

The above statements indicate that the study sample's individuals prefer herbal medication, recommend them to patients as they have positive attitudes regarding these remedies when being compared to chemical ones.
Also, six statements got a moderate degree and their means ranged between (2.73-3.58). The study sample individuals' responses varied regarding these statements that got the following arrangement: Statement no. (11) "I feel more confident in using $\mathrm{Hb}$ " got the sixth rank $(\mathrm{M} .=3.58)$. Statement no. (5) "whole drugs are used in herbal treatments" got the rank before the last (M.=3.11). Statement no. (17) "I feel reluctant in taking $\mathrm{Hb}$ " got the last rank $\left(M_{.}=2.73\right)$. These statements indicate that some of the study sample individuals trust using herbal remedies as they believe in its importance and the effective role it plays in treatment.

Furthermore, above statements indicate that some of the study sample individuals are hesitant to use herbal remedies as they do not believe in its effective role it plays in treatment.

Table (4): Percentages, means, and standard deviations of study sample individuals' responses concerning Orthodox (OR).

\begin{tabular}{|c|c|c|c|c|c|c|c|c|c|}
\hline \multirow[b]{2}{*}{ No } & \multirow{2}{*}{ Statements } & \multicolumn{5}{|c|}{ Percentages } & \multirow[b]{2}{*}{ Mean } & \multirow{2}{*}{$\begin{array}{c}\text { Std. } \\
\text { deviation }\end{array}$} & \multirow{2}{*}{$\begin{array}{l}\text { Order } \\
\text { according } \\
\text { to mean }\end{array}$} \\
\hline & & $\begin{array}{c}\text { Strongly } \\
\text { disapprove }\end{array}$ & Disapprove & $\begin{array}{c}\text { No } \\
\text { comment }\end{array}$ & Approve & $\begin{array}{l}\text { Strongly } \\
\text { approve }\end{array}$ & & & \\
\hline 2 & - I prefer Orthodox treatment. & 2.20 & 17.58 & 29.67 & 44.51 & 6.04 & 3.35 & 0.91 & 5 \\
\hline 4 & - Orthodox has fewer side effects. & 6.59 & 32.97 & 28.57 & 23.63 & 8.24 & 2.94 & 1.08 & 8 \\
\hline 6 & - Whole drugs are used in Orthodox. & 9.34 & 21.43 & 27.47 & 32.42 & 9.34 & 3.29 & 1.12 & 6 \\
\hline 9 & - Orthodox needs a long time to show effect. & 6.59 & 18.68 & 27.47 & 34.07 & 13.19 & 2.68 & 1.11 & 10 \\
\hline 12 & - Or is better for acute cases & 13.19 & 38.46 & 19.78 & 24.18 & 4.40 & 3.64 & 1.15 & 1 \\
\hline 13 & $\begin{array}{l}\text { - Or contains concentrated amounts of single } \\
\text { active constituents. }\end{array}$ & 5.49 & 11.54 & 21.98 & 35.16 & 25.82 & 3.55 & 1.07 & 4 \\
\hline 15 & - I feel more confident using Or. & 5.49 & 11.54 & 21.98 & 44.51 & 16.48 & 3.10 & 1.15 & 7 \\
\hline 16 & $\begin{array}{l}\text { - I feel reluctant in taking or after hearing } \\
\text { about continuous drug recalls. }\end{array}$ & 9.89 & 20.88 & 29.67 & 28.57 & 10.99 & 3.62 & 1.04 & 3 \\
\hline 18 & - Or is treated by the body as an alien. & 2.75 & 14.29 & 20.88 & 42.86 & 19.23 & 3.62 & 1.01 & 2 \\
\hline 29 & - I recommend Or. & 3.33 & 12.22 & 20.00 & 47.78 & 16.67 & 2.94 & 1.14 & 9 \\
\hline
\end{tabular}

Based on the above table, it is notable that the Orthodox (OR) axe has (10) statements and that all its statements had a moderate degree as their means ranged between (2.68-3.64). Also, the study sample individuals' responses varied in regard to these statements that got the following arrangement: Statement no. (12) " Or is better for acute cases" got the first rank (M.=3.64). Statement no. (18) " Or is treated by the body as an alien" got the second rank (M.=3.62). Statement no. (16) " I feel reluctant in taking or after hearing about continuous drug recalls" got the third rank $(M .=3.62)$. These statements point out that some of the study sample individuals believe in using chemical remedies in treating the acute cases as they will be more effective than the herbal remedies.

Also, some students feel hesitant to use chemical remedies. Statement no. (29) "I recommend Or " got the rank before the last rank $(M .=2.94)$. Statement no. (9) " Orthodox needs a long time to show effect" got the last rank $(M .=2.68)$. These statements illustrate that some of the study sample individuals recommend using chemical remedies while others believe that they need a long time to show their effect.

Table (5): Percentages, means, and standard deviations of study sample individuals' responses concerning supplemental and beauty products.

\begin{tabular}{|c|c|c|c|c|c|c|c|c|c|}
\hline \multirow{2}{*}{ No } & \multirow{2}{*}{ Statements } & \multicolumn{5}{|c|}{ Percentages } & \multirow{2}{*}{ Mean } & \multirow{2}{*}{$\begin{array}{c}\text { Std. } \\
\text { deviation }\end{array}$} & \multirow{2}{*}{$\begin{array}{c}\text { Order } \\
\text { according } \\
\text { to mean }\end{array}$} \\
\hline & & $\begin{array}{c}\text { Strongly } \\
\text { disapprove }\end{array}$ & $\begin{array}{c}\text { Dis- } \\
\text { approve }\end{array}$ & $\begin{array}{c}\text { No } \\
\text { comment }\end{array}$ & Approve & $\begin{array}{l}\text { Strongly } \\
\text { approve }\end{array}$ & & & \\
\hline 19 & I use some sort of $\mathrm{Hb}$. Products daily. & 3.85 & 15.38 & 16.48 & 46.15 & 18.13 & 3.59 & 1.07 & 2 \\
\hline 20 & I use some sort of Or. Products daily. & 15.38 & 31.87 & 18.68 & 28.57 & 5.49 & 2.77 & 1.18 & 5 \\
\hline 23 & I prefer supplementary and beauty $\mathrm{Hb}$. Products. & 2.20 & 6.04 & 8.7 & 46.15 & 36.81 & 4.09 & 0.94 & 1 \\
\hline 24 & I prefer supplementary or beauty products. & 10.99 & 26.37 & 26.92 & 27.47 & 8.24 & 2.96 & 1.15 & 4 \\
\hline 25 & I think most supplementary and beauty products are $\mathrm{Hb}$. & 2.20 & 21.98 & 19.78 & 36.26 & 19.78 & 3.49 & 1.11 & 3 \\
\hline
\end{tabular}


Based on the above table, it is notable that the axe of supplemental and beauty products has (5) statements and that the study sample individuals' responses varied in regard to these statements that got the following arrangement: Statement no. (23) "I prefer supplementary and beauty $\mathrm{Hb}$. Products " got the first rank (M.=4.09). Statement no. (19) " I use some sort of $\mathrm{Hb}$. products daily" got the second rank (M.=3.59). Statement no. (20) "I use some sort of Or products daily" got the last rank $(M .=2.77)$, and with a moderate degree. These statements indicate that some of the study sample individuals prefer using beauty $\mathrm{Hb}$. Products as they trust them, and some others prefer using $\mathrm{Hb}$. products daily as they believe in their importance and the lack of their side effects when being compared with chemical one from their own viewpoint.

Table (6): Percentages, means, and standard deviations of study sample individuals' responses concerning Legislation.

\begin{tabular}{|c|c|c|c|c|c|c|c|c|}
\hline \multirow[b]{2}{*}{ Statements } & \multicolumn{5}{|c|}{ Percentages } & \multirow{2}{*}{ Mean } & \multirow{2}{*}{$\begin{array}{c}\text { Std. } \\
\text { deviation }\end{array}$} & \multirow{2}{*}{$\begin{array}{c}\text { Order } \\
\text { according } \\
\text { to mean }\end{array}$} \\
\hline & $\begin{array}{l}\text { Strongly } \\
\text { disapprove }\end{array}$ & $\begin{array}{l}\text { Dis- } \\
\text { approve }\end{array}$ & $\begin{array}{l}\text { No } \\
\text { comment }\end{array}$ & Approve & $\begin{array}{l}\text { Strongly } \\
\text { approve }\end{array}$ & & & \\
\hline 26 There not enough legislative control on $\mathrm{Hb}$. & 12.09 & 12.09 & 23.08 & 24.18 & 28.57 & 3.45 & 1.34 & 3 \\
\hline 27 There is not enough legislative control on or. & 9.89 & 18.13 & 16.48 & 34.07 & 21.43 & 3.39 & 1.28 & 4 \\
\hline $\begin{array}{l}35 \cdot \text { There should be more professional herbal } \\
\text { treatment centers in Kuwait. }\end{array}$ & 1.10 & 6.59 & 9.89 & 37.36 & 45.05 & 4.19 & 0.94 & 1 \\
\hline $\begin{array}{l}\text { 36 }- \text { Hb should sell only crude drugs not } \\
\text { pharmaceutical products. }\end{array}$ & 6.04 & 15.93 & 21.98 & 28.57 & 27.47 & 3.55 & 1.22 & 2 \\
\hline
\end{tabular}

Based on the above table, it is notable that the legislation axe has (4) statements and that the study sample individuals' responses varied in regard to these statements that got the following arrangement: Statement no. (35) " there should be more professional herbal treatment centers in Kuwait" got the first rank $(M .=4.19)$ and with a high degree. Statement no. (36) " Hb should sell only crude drugs not pharmaceutical products" got the second rank $(M .=3.55)$ and with a moderate degree. Statement no. (27) " there is not enough legislative control on or" got the last rank (M.=3.39), and with a moderate degree. These statements indicate that most of the study sample individuals believe in the importance of having herbal treatment centers in Kuwait, as there are no enough herbal treatment centers, as they trust herbal remedies believing that they have no side effects from their own viewpoints. Also, some of the some of the study sample individuals believe that there is no enough legislative control on or and thus there must be much censorship on these remedies.

Table (7): Percentages, means, and standard deviations of study sample individuals' responses concerning general information.

\begin{tabular}{|c|c|c|c|c|c|c|c|c|}
\hline \multirow[b]{2}{*}{ Statements } & \multicolumn{5}{|c|}{ Percentages } & \multirow{2}{*}{ Mean } & \multirow{2}{*}{$\begin{array}{c}\text { Std. } \\
\text { deviation }\end{array}$} & \multirow{2}{*}{$\begin{array}{l}\text { Order } \\
\text { according } \\
\text { to mean }\end{array}$} \\
\hline & $\begin{array}{c}\text { Strongly } \\
\text { disapprove }\end{array}$ & $\begin{array}{c}\text { Dis- } \\
\text { approve }\end{array}$ & $\begin{array}{c}\text { No } \\
\text { comment }\end{array}$ & Approve & $\begin{array}{l}\text { Strongly } \\
\text { approve }\end{array}$ & & & \\
\hline $21 \cdot$ I think they complement each other. & 6.11 & 11.67 & 23.33 & 37.78 & 21.11 & 3.56 & 1.13 & 5 \\
\hline $22 \cdot$ I think one could do without the other. & 8.24 & 24.18 & 17.58 & 34.07 & 15.93 & 3.25 & 1.22 & 6 \\
\hline $\begin{array}{l}\text { 30 Most patients have no Idea about } \mathrm{Hb} \text { treatment } \\
\text { center in Kuwait. }\end{array}$ & 1.65 & 10.44 & 15.38 & 41.76 & 30.77 & 3.90 & 1.01 & 1 \\
\hline $\begin{array}{l}\text { 31 At the Islamic medicine center only safe and } \\
\text { scientifically proved herbs are used. }\end{array}$ & 3.30 & 12.64 & 20.88 & 34.62 & 28.57 & 3.73 & 1.11 & 3 \\
\hline $32 \cdot$ A lot of people can't afford Or. & 3.30 & 7.14 & 19.78 & 43.96 & 25.82 & 3.82 & 1.01 & 2 \\
\hline $\begin{array}{l}\text { 33- Most or treatment centers concentrate on profit } \\
\text { making by treating the recurrent symptoms. }\end{array}$ & 3.30 & 10.99 & 19.78 & 45.05 & 20.88 & 3.69 & 1.03 & 4 \\
\hline
\end{tabular}

Based on the above table, it is notable that the general information axe has (6) statements and that the study sample individuals' responses varied in regard to these statements that got the following arrangement: Statement no. (30) " most patients have no Idea about $\mathrm{Hb}$ treatment center in Kuwait" got the first rank $(M .=3.90)$ and with a high degree. Statement no. (32) " A lot of people can't afford Or" got the second rank (M.=3.82) and with a high degree. These statements indicate that most of the study sample individuals believe that the majority of patients in Kuwait have no information about herbal treatment centers in Kuwait so there must be enlightening programs about these centers to make use of the services they provide for patients.

Statement no. (21) " I think they complement each other" got the rank before the last rank (M.= 3.56 ), and with a moderate degree. Statement no. (22) "I think one could do without the other" got the last rank $(M=3.25)$, and with a moderate degree. These statements indicate that some of the study 
sample individuals believe herbal and chemical remedies are complementary and thus one could not do without any one of them.

\section{Results of the second question:}

Are there statistically significant differences among the averages of the study sample individuals concerning herbal and chemical remedies due to the variable of gender?

To identify the differences among the averages of the study sample individuals concerning herbal and chemical remedies according to the variable of gender, independent sample $t$-test, has been used. The results are shown in the following tables:

Table (8): Results of $t$-test to examine the differences among the averages of study sample individuals' responses concerning herbal and chemical remedies according to the variable of gender.

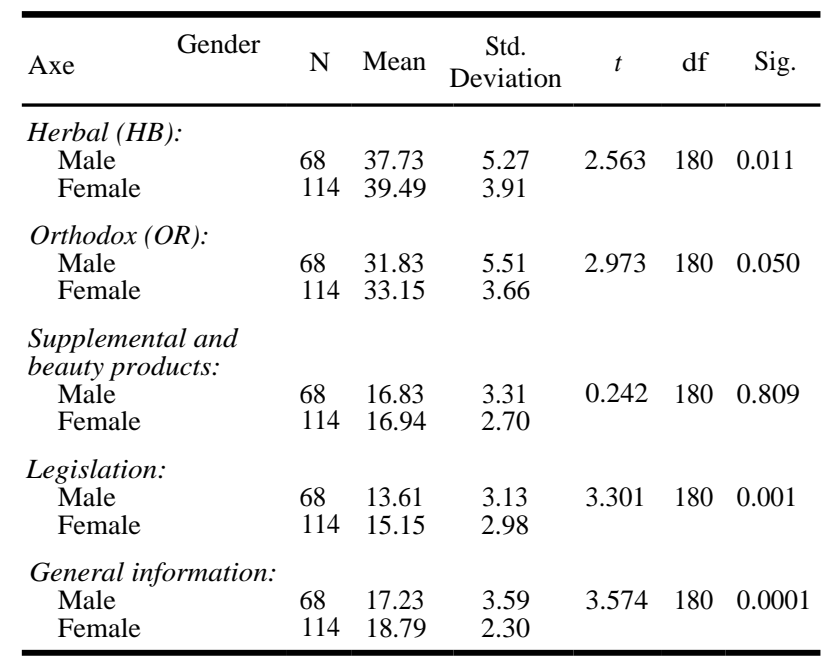

Based on the above table, it is apparent that there are statistically significant differences at the significance level (0.05) among study sample individuals concerning responses concerning the next fields: Herbal (HB), Orthodox (OR), legislation, general information due to the variable of gender in favor of females as ( $\mathrm{t}$ )'s calculated value reached (2.563), (2.973), (3.301), (3.574), respectively and its significance level is less than $(0.05)$. This can be interpreted by the fact that females are more aware of the previous fields than males. Females are more interested in reading about everything relevant to herbal and chemical remedies than males.

Additionally, there are no statistically significant differences regarding the field of supplemental and beauty products due to the variable of gender as (t)'s calculated value reached (0.242), and its significance level is more than (0.05). This can be interpreted as result of the agreement among the study sample individuals on supplemental and beauty products regardless their gender.

\section{Results of the third question:}

Are there statistically significant differences among the averages of the study sample individuals concerning herbal and chemical remedies due to the variable of specialization?

To identify the differences among the averages of the study sample individuals concerning herbal and chemical remedies according to the variable of specialization, one Way ANOVA has been used. The results are shown in the following tables:

Table (9): Results of one Way ANOVA to examine the differences among the averages of study sample individuals' responses concerning herbal and chemical remedies according to the variable of specialization.

\begin{tabular}{|c|c|c|c|c|c|c|c|c|c|c|}
\hline Axe & Section & $\mathrm{N}$ & Mean & $\begin{array}{c}\text { Std. } \\
\text { deviation }\end{array}$ & Variance & $\begin{array}{l}\text { Sum of } \\
\text { squares }\end{array}$ & df & $\begin{array}{l}\text { Mean } \\
\text { square }\end{array}$ & $\mathrm{F}$ & Sig. \\
\hline - Herbal (HB) & $\begin{array}{l}\text { Pharmacy } \\
\text { Dental health } \\
\text { Environmental health } \\
\text { Total }\end{array}$ & $\begin{array}{l}112 \\
49 \\
21 \\
182\end{array}$ & $\begin{array}{l}39.69 \\
37.57 \\
37.19 \\
38.83\end{array}$ & $\begin{array}{l}4.33 \\
4.41 \\
4.96 \\
4.54\end{array}$ & $\begin{array}{l}\text { Between groups } \\
\text { Within groups } \\
\text { Total }\end{array}$ & $\begin{array}{l}218.138 \\
3512.917 \\
3731.055\end{array}$ & $\begin{array}{l}2 \\
179 \\
181\end{array}$ & $\begin{array}{l}109.069 \\
19.625\end{array}$ & 5.55 & 0.005 \\
\hline - Orthodox (OR) & $\begin{array}{l}\text { Pharmacy } \\
\text { Dental health } \\
\text { Environmental health } \\
\text { Total }\end{array}$ & $\begin{array}{l}112 \\
49 \\
21 \\
182\end{array}$ & $\begin{array}{l}33.28 \\
31.65 \\
31.71 \\
32.66\end{array}$ & $\begin{array}{l}4.52 \\
4.69 \\
3.05 \\
4.47\end{array}$ & $\begin{array}{l}\text { Between groups } \\
\text { Within groups } \\
\text { Total }\end{array}$ & $\begin{array}{l}112.310 \\
3520.245 \\
3632.555\end{array}$ & $\begin{array}{l}2 \\
179 \\
181\end{array}$ & $\begin{array}{l}56.155 \\
19.666\end{array}$ & 2.85 & 0.050 \\
\hline $\begin{array}{l}\text { - Supplemental and } \\
\text { beauty products }\end{array}$ & $\begin{array}{l}\text { Pharmacy } \\
\text { Dental health } \\
\text { Environmental health } \\
\text { Total }\end{array}$ & $\begin{array}{l}112 \\
49 \\
21 \\
182\end{array}$ & $\begin{array}{l}16.89 \\
16.77 \\
17.28 \\
16.90\end{array}$ & $\begin{array}{l}2.70 \\
3.58 \\
2.55 \\
2.93\end{array}$ & $\begin{array}{l}\text { Between groups } \\
\text { Within groups } \\
\text { Total }\end{array}$ & $\begin{array}{l}3.881 \\
1559.531 \\
1563.412\end{array}$ & $\begin{array}{l}2 \\
179 \\
181\end{array}$ & $\begin{array}{l}1.941 \\
8.712\end{array}$ & 0.22 & 0.801 \\
\hline - Legislatio & $\begin{array}{l}\text { Pharmacy } \\
\text { Dental health } \\
\text { Environmental health } \\
\text { Total }\end{array}$ & $\begin{array}{l}112 \\
49 \\
21 \\
182\end{array}$ & $\begin{array}{l}14.83 \\
14.12 \\
14.33 \\
14.58\end{array}$ & $\begin{array}{l}3.14 \\
3.30 \\
2.57 \\
3.12\end{array}$ & $\begin{array}{l}\text { Between groups } \\
\text { Within groups } \\
\text { Total }\end{array}$ & $\begin{array}{l}18.555 \\
1751.709 \\
1770.264\end{array}$ & $\begin{array}{l}2 \\
179 \\
181\end{array}$ & $\begin{array}{l}9.277 \\
9.786\end{array}$ & 0.94 & 0.389 \\
\hline - General information & $\begin{array}{l}\text { Pharmacy } \\
\text { Dental health } \\
\text { Environmental health } \\
\text { Total }\end{array}$ & $\begin{array}{l}112 \\
49 \\
21 \\
182\end{array}$ & $\begin{array}{l}18.16 \\
18.63 \\
17.52 \\
18.21\end{array}$ & $\begin{array}{l}2.98 \\
2.92 \\
2.74 \\
2.94\end{array}$ & $\begin{array}{l}\text { Between groups } \\
\text { Within groups } \\
\text { Total }\end{array}$ & $\begin{array}{l}18.910 \\
1551.733 \\
1570.643\end{array}$ & $\begin{array}{l}2 \\
179 \\
181\end{array}$ & $\begin{array}{l}9.455 \\
8.669\end{array}$ & 1.09 & 0.338 \\
\hline
\end{tabular}


Based on the above table, it is remarkable that there are no statistically significant differences at the significance level (0.05) among study sample individuals concerning responses concerning the next fields: Supplemental and beauty products, legislation, general information due to the variable of specialization as (f)'s calculated value reached (0.22), (0.94), (1.09), respectively and its significance level is more than (0.05). It can be said that this is owing to the agreement among the study sample individuals on supplemental and beauty products regardless their gender.

Furthermore, there are statistically significant differences regarding the fields of: Herbal (HB), Orthodox (OR) due to the variable of specialization as (f)'s calculated value reached (5.55), (2.85), and its significance level is less than (0.05). To identify the statistical significances, LSD has been used as illustrated in the following table.

Table (10): Results of (LSD) to reveal the differences among the averages of study sample individuals' responses concerning herbal and chemical remedies according to the variable of specialization.

\begin{tabular}{|c|c|c|c|c|}
\hline Axe & Section & Pharmacy & $\begin{array}{l}\text { Dental } \\
\text { health }\end{array}$ & $\begin{array}{c}\text { Environ- } \\
\text { mental } \\
\text { health }\end{array}$ \\
\hline $\begin{array}{c}\cdot \text { Herbal } \\
\text { (HB) }\end{array}$ & $\begin{array}{l}\text { Pharmacy } \\
\text { Dental health } \\
\text { Environmental health }\end{array}$ & & $2.125 * *$ & $\begin{array}{l}2.506^{* * *} \\
0.381\end{array}$ \\
\hline $\begin{array}{l}\text { - Orthodox } \\
\text { (OR) }\end{array}$ & $\begin{array}{l}\text { Pharmacy } \\
\text { Dental health } \\
\text { Environmental health }\end{array}$ & & $1.632 * *$ & $\begin{array}{l}1.571 \\
-0.061\end{array}$ \\
\hline
\end{tabular}

**: Significant at the (0.05) level.

Based on the above table, it is notable that there are statistically significant differences at the significance level (0.05) among the students at the Colleges of Pharmacy and Dental Health regarding the field of Herbal (HB) in favor of Pharmacy students. Also, there are statistically significant differences among the students at the Colleges of Pharmacy and Dental Health regarding the field of Orthodox (OR) in favor of Pharmacy students. This can be interpreted by the fact that students at the College of Pharmacy are more aware of herbal and chemical remedies than students of other different specializations as their future profession necessitate having great information about the nature and the different usages of theses remedies.

\section{Discussion}

In the light of the results of this study, the researcher recommends the following:

- There should be posters and banners at the College of Health Sciences about the nature of herbal remedies.

- There should be posters and banners at the College of Health Sciences to illustrate the differences between herbal and chemical remedies.

- There should be enlightening programs for the citizens in society about the importance of herbal remedies illustrating that they have no side effects.

- The importance of having centers which provide herbal treatment in Kuwait.

- The importance of providing patients in Kuwait with more information about herbal treatment.

- The Ministry of Health in Kuwait should have a greater censorship on chemical remedies.

- Advising people in general and patients in particular not to use chemical remedies unless prescribed by a physician to avoid their side effects.

- Asserting the importance of consulting a physician when using herbal medication for a purpose to make sure that it is suitable for the treatment to avoid have a long period of sickness when using inappropriate medication.

Suggested researches:

As an extension to the results of the current study, the researcher recommends the following researches:

- Conducting researches and studies on the nature of herbal remedies as compared to chemical remedies on new samples different from those of the current study.

- Performing researches and studies on the effect of herbal remedies in treating some diseases for patients in the State of Kuwait.

- Carrying out researches and studies on the side effects of some chemical remedies.

\section{Statistics:}

Using the scale 1 for strongly disapprove, 2 disapprove, 3 no comment, 4 approve, 5 strongly approve questionnaire results to be calculated compared and analyzed statistically. 


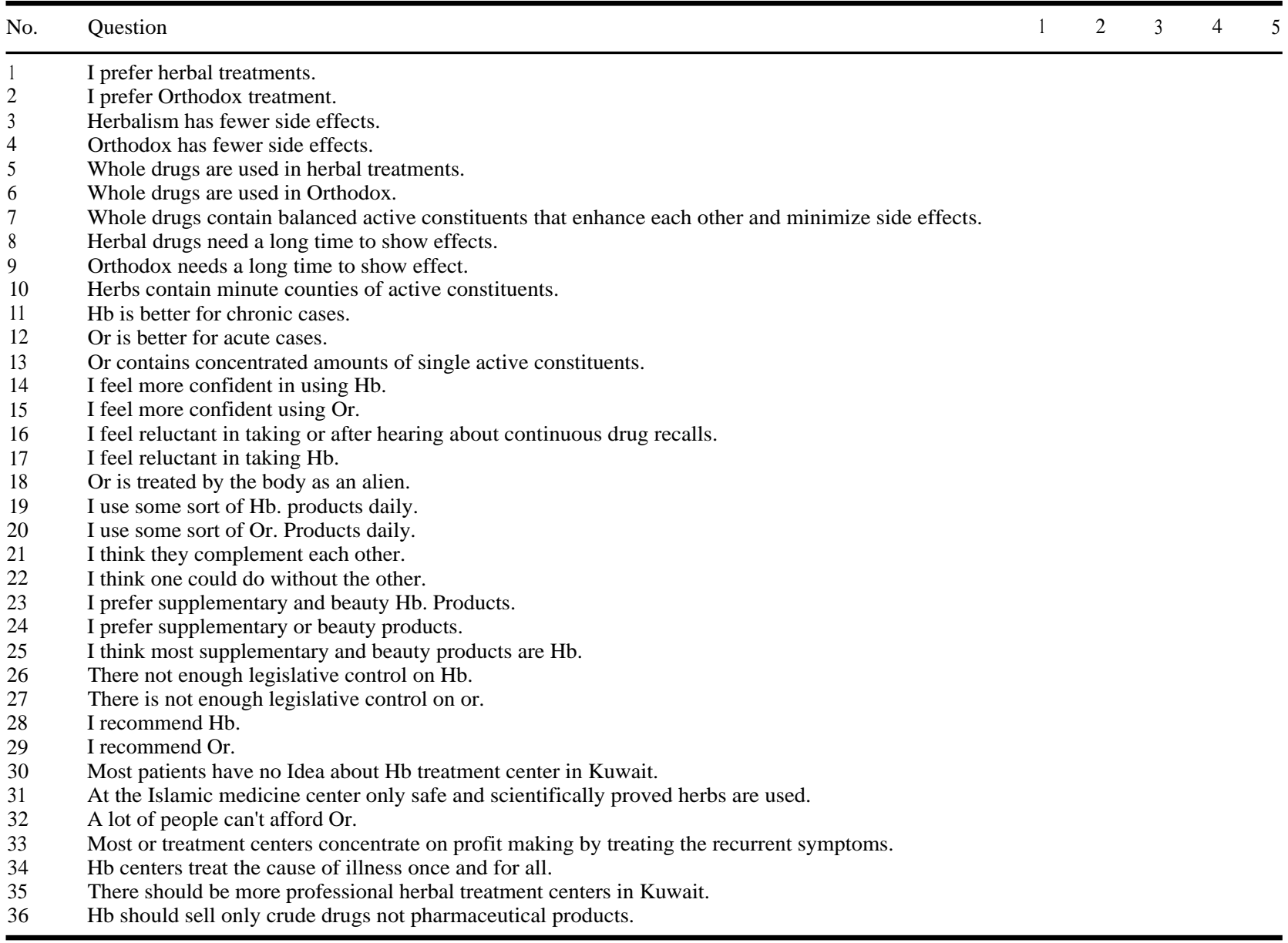

\section{References}

1- The Herbal Remedies ACT-World Health OrganizationKuwait-21-23 April 1986.

2- MARAKOVA A., SAROKINA A. FEDRA VESKII N. and SERGUNOVA E.: Russian Chemical Bulletin. May, vol. 63, issue 5, P1251-1254. Advantages of using potentiometry for determination of active components (tannius, organic acids in herbal view), 2014.

3- SIMIN Z., LAUALAN D., YUAN H. and HONG X. American journal of Chinese medicine, vol 45, issue 7, p. 1327-1344. The use of traditional Chinese medicine and acupuncture, herbal medicine in Alzheimer"Is disease treatment, 2017.

4- NILOO A., SHADE V. and JAVAD B.: Avicenna journal of phytomedicine. Supplement vol. 5, p 3. Hoeopathy, herbal medicine in treatment of female infertility, 2015.

5- SAHOO N., MANCHIKAUTI P. and DEY S.: Journal of eathropharmacology. Sep., vol. 137, issue 1, p. 289-97. Herbal drug patenting in india: IP potential, 2011.

6- LIU Y. and WANG M.: Life science journal. Feb. 2008 , vol. 82, issue 9/10, p 445-449. Botanical drugs: Challenges and opportunities, contribution to linaaeus memorial symposium 2007.

7- DUKE, JAMES A.: «Better Nutrition. Nov., vol. 62, issue 11, p 78. Advantage pherbal products over drugs, 2011.
8- LAPIDUS M.: Educating pharmacy students about herbal medicine. Health info and libraries J. vol. 24, issue 4, p. 267-73, 2007

9- TAPPER J.: The natural first aid handbook library journal. Vol 142, issue 13, p. 110-10, 2017.

10- DUKE J.: Alternative cares. Vol 247, issue 45, p. 88, 2000.

11- GREINER K.A., et al.: Medical students intrest inalternative medicine. J. Alt. Comp. Med., 6: 231-4, 2000

12- EILKINSON J.M. and SIMPSON M.D.: Complimentary therapy use by nersing, pharmacy and biomedical Science students. Nurs Health sci., 3: 19-27, 2001.

13- KRIETZER M.J., et al.: Attitudes towards CAM among nursing, medical and Pharmcy faculty and students; a comparative analysis. Altern Ther. Health Med., 8: 44-7, 50-3, 2002.

14- BARNS P.M., et al.: Complementary and alternative Medicine use among adults and children; United States. Nat. Health Stat. Report, 12: 1-23, 2008.

15- AL BRAIK F.A., et al.: A crosssctional survey of herbal remedies taken by uae citizins in Pharmacopedemiol Drug Saf., 17: 725-32, 2008

16-ALRUWAIS N., et al.: Traditional Healers in Ryad reagon. J. Altern. Comp. Med., 16: 199-204, 2010.

17-TSURUOKA K., et al.: Complementary medical education in Japanese medical schools, 9: 228-33, 2001. 


\section{شعبية طب الآعشاب}

هذا البحث يلقى الضوء على مدى شعبية ووعى المواطن الكويتى عن الفرق بين الآدوية العشبية والآدوية الكيميائية من خلال إستبيان مفصل

عن آراء طلاب وطالبات كلية العلوم الصحية.

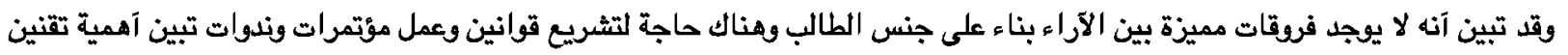

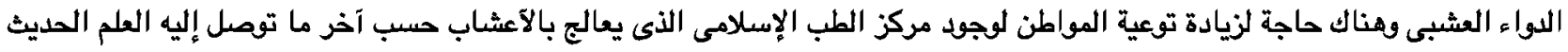
من حيث فعالية وآمان المنتج العشبى. لرياء تصعي 